Apidologie, 1985, 16 (3), 265-274

\title{
AN IMMUNO-ELECTROPHORETICAL ANALYSIS OF SOLUBLE BLOOD PROTEINS OF COILED AND UPRIGHT LARVAE OF THE WORKER HONEY BEE, APIS MELLIFERA
}

\author{
Zdzislaw GLINSKI*, Jan JAROSZ, Andrzej WERNICKI* \\ * Dee Diseases Laboratory, Institute of Infectious and Invasive Diseases, \\ Agricultural University, Lublin \\ Unit of Insect Pathology, M. Curie-Sklodowska University, \\ Lublin, Akademicka 19, Poland
}

\begin{abstract}
SUMMARY
Undegraded proteins in blood of coiled and upright worker honey bee larvae were analyzed using polyacrylamide gel electrophoresis under non-denaturating buffer system and immuno- techniques. The number of protein fractions in larval blood of the both developmental stages of the bee is not numerous; only six protein bands are found on acrylamide gel. In both larval stages they are composed of 14 serologically reactive identical proteins and a unique protein occurring only in upright larvae. Only this unique protein complex differs statistically in the two larval stages.
\end{abstract}

\section{INTRODUCTION}

In recent years, considerable attention has been paid to the characterization of haemolymph proteins and understanding of their role in metamorphosis of insects, by use of acrylamide gel electrophoresis, electrofocusing and immunetechniques. Nevertheless, the effects of developmental changes on structure and function at both cellular and supracellular levels are far from understood. Even the most elementary data are lacking for commonly occurring insect species.

The number and kind of different protein fractions in insect blood plasma is highly variable, according to species and ontogenic stage. In most insects so far studied, the total protein concentration increases during larval life, then decreases at the end of the pupal stage, and during adult life. Metamorphosis 
is also often accompanied by qualitative variations in protein composition of the blood.

As Norman et al. (1967), have reported, among the fourteen different protein fractions of the haemolymph of Anthonomus grandis, there is one fraction unique to the larval stage and another unique to the pupal stage. The last larval ecdysis, pupation and adult emergence of the large white butterfly, Pieris brassicae, were associated with notable changes in the pattern of haemolymph proteins and lipoproteins (TORUNEN, 1978). Slowly migrating lipoproteins were prominent in newly oviposited eggs and in fifth instar larvae, but were almost absent from molting fourth to fifth instar larvae and 2 day old pupae. The protein analyses of whole blood of the lawn armyworm, Spodoptera mauritis acronyctoides have revealed an increase in the quantity of haemolymph proteins and the appearance of some new proteins as the larva aged (TAKEI and TAMASHIRO, 1975). Chen and LevenBook (1966) also found changes in density of blood protein fractions in the blowfly, Phormia regina, as did Parker (1971) in the Colorado potato beetle, Leptinotarsa decemlineata.

By means of immunoelectrophoretic methods LENSKY (1971) was able to identify in the honey bee, Apis mellifera, three main protein patterns, one present throughout the whole development, and one specific to the larval stage and one specific to the adult stage. Also, Bounias (1975) has shown some modifications of the protein pattern which appear during the development.

Using gel electrophoresis and immunoelectrophoresis we report the detection and partial characterization of undegraded soluble blood protein fractions in the two developmental stages of worker honey bee larvae, Apis mellifera. Evidence is also given for differences in protein composition of the coiled and the upright larvae which suggests the possible developmental changes.

\section{MATERIALS AND METHODS}

Bee haemolymph. Samples of blood, $5 \mu$ l each, for experimental trials were obtained from the coiled worker larvae (brood about 8 days old) and the upright larvae (9-10 days old) from a honey bee (Apis mellifera mellifera) colony in summer. Bees were free from diseases. Haemolymph was withdrawn by puncturing cuticle of the dorsal region of the larva with a 5 ul automatic glass micropiptte. A trace amount of phenylthiourea was added to the samples to inhibit phenyloxidase activity.

For electrophoresis on acrylamide gel to determine similarities or differences in patterns of soluble blood proteins, among the particular individuals and the two developmental stages, an aliquot of $5 \mu \mathrm{l}$ of blood from a single bee was placed into $50 \mu \mathrm{l}$ of $1.0 \mathrm{M}$ sucrose. However, production of antisera and immunoelectrophoretic analysis were performed on pooled samples of haemolymph previously centrifuged at $15000 \mathrm{~g}$ for $10 \mathrm{~min}$ at $4{ }^{\circ} \mathrm{C}$. 
Electrophoretic fractionation. Acrylamide gel electrophoresis using a discontinuous buffer system without sodium dodecylsulphate (SDS) was carried out in $10 \%$ separation gel. The stacking $3 \%$ gel (0.125 $\mathrm{M}$ Tris-HCl, $\mathrm{pH} 6.8)$ and the separation gel $(0.375 \mathrm{M}$ Tris- $\mathrm{HCl}, \mathrm{pH} 8.8)$ were prepared according to LAEMMLI (1970). The running buffer was composed of $0.025 \mathrm{M}$ Tris and $0.192 \mathrm{M}$ glycine (pH 8.5). Thirty microliter samples of the blood-sucrose mixture, equivalent to $2.73 \mu 1$ whole haemolymph, were applied on the top of the gel $(6.0 \times 95.0 \mathrm{~mm})$. Bromophenol blue was used as the marker dye. A constant current of $0.8 \mathrm{~mA} /$ tube was applied overnight at room temperature. Electrophoresis was completed when tracking dye migrated to the region about $1 \mathrm{~cm}$ above the bottom of the gel. After removal, gels were fixed for $6 \mathrm{~h}$ in $50 \%$ trichloroacetic (TCA) solution. The gels were then stained in acetic acid : methanol : water $(5: 14: 56 \mathrm{v} / \mathrm{v})+12 \%$ TCA containing $0.02 \%$ Coomassie blue R-250 and destained in acetic acid : methanol : water (4:24:56, $\mathrm{v} / \mathrm{v}$ ) (LAEMmLI, 1970). Electrophoregrams and their analyses were obtained after scanning of gels at $595 \mathrm{~nm}$ with VT-Vitatron densitometr equipment. The location of a band in each gel was expressed as relative mobility $\left(R_{m}\right)$ and was defined as the distance that the given band migrated from the origin divided by the distance travelled by the marker.

Preparation of antisera. Antibodies to soluble blood proteins of the coiled and upright larvae were prepared in rabbits. An aliquot of $0.2 \mathrm{ml}$ haemolymph, free of cellular elements and emulsified in an equal volume of Freund's complete adjuvant was injected subcutaneously 7 times at 5 day intervals. The total dose of injected proteins was $11.9 \mathrm{mg} / \mathrm{rabbit}$. The animals were bled on the 7th day after the last injection of the antigen. Antisera were heated at $56{ }^{\circ} \mathrm{C}$ for $30 \mathrm{~min}$ and then stored after lyophilization at $-20^{\circ} \mathrm{C}$ until use.

Immunoelectrophoresis. One-dimensional immunoelectrophoresis was performed according to Grabar and Williams (1955), using $1 \%$ agarose buffered with $0.1 \mathrm{M}$ sodium barbital to pH 8.6. The separation was carried out during $3.0-3.5 \mathrm{~h}$ at $250 \mathrm{~V} /$ plate. Undiluted rabbit antiserum against the whole insect blood proteins was used in all trials. The patterns of precipitation arcs were visualized after $72 \mathrm{~h}$ of incubation at $25^{\circ} \mathrm{C}$ in moistened chambers. No new precipitation lines appeared after a prolongation of incubation time.

Cross-absorption tesi. To obtain a more detailed analysis of serological identities of blood proteins, the cross-absorption test was done using two antisera and corresponding larval hacmolymphs. Equal volumes of haemolymph of coiled larva and antiserum against upright larval proteins were mixed, and vice-versa. The mixture was incubated for $1 \mathrm{~h}$ at $35^{\circ} \mathrm{C}$ and centrifuged (Young III and ScoTr, 1970); then used for immunoelectrophoresis.

Statistical analysis. After densitometer scanning of the gels the relative percent of each protein fraction was compared statistically. Mean values (arythmetic means \pm standard deviation) were included in statistical analysis. A t-test was used to determine whether or not differences between mean values are significant.

\section{RESULTS}

Taking into account the fact that a variety of buffer systems thus far were applied to fractionate the soluble blood proteins using electrophoresis and other analytical techniques we decided to clarify ultimately the number of intact protein complexes that occur in larval haemolymph of the two well-defined developmental stages of the bee, coiled and upright larva. Fig. 1 and 2 show the patterns of soluble proteins in larval blood, densitometer scans and relative percent of individual protein fractions. Fraction 1 of the two larval stages differs significantly $(P \leqslant 0.01)$. Electrophoresis always reveals 6 well-defined protein bands, 


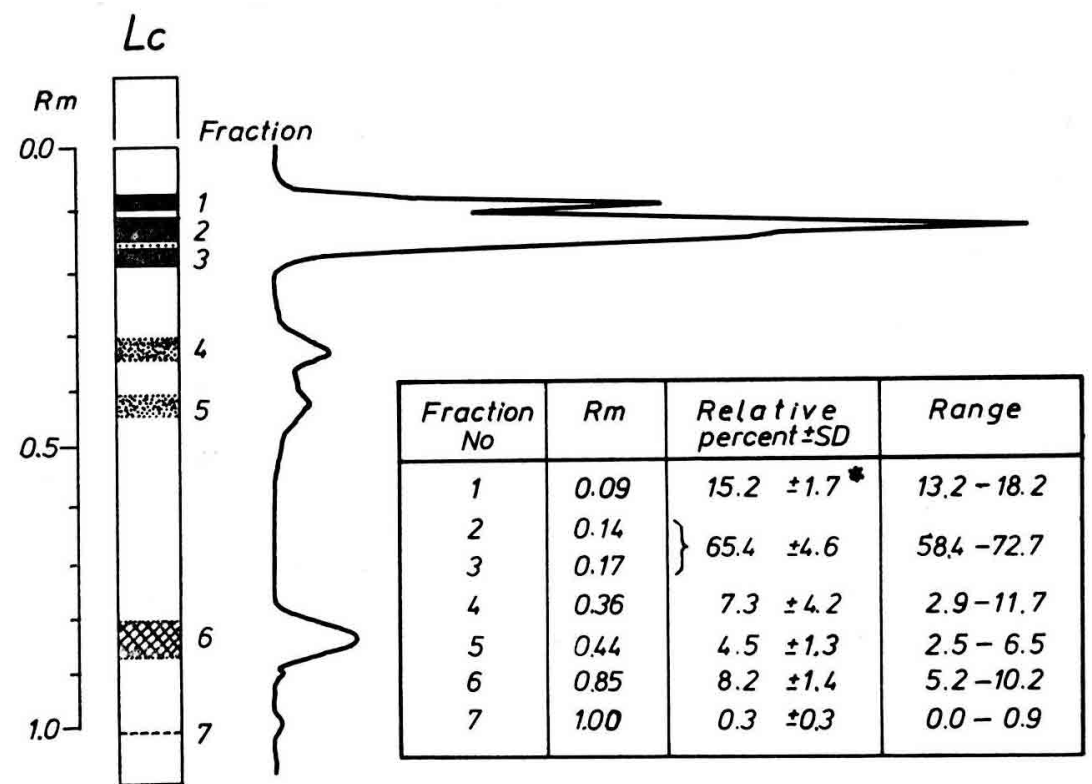

FIG. 1. - Polyacrylamide gel electrophoresis patterit of soluble Apis blood proteins of coiled larva $(\mathrm{Lc})$ and densitometer scan of the gel after non-dissociating electrophoresis of proteins in $10 \%$ acrylamide

* denotes statistically significant différences $(\mathbf{P} \leq 0.01, \mathrm{n}=12)$

and in majority of individuals, an accessory faintly-stained fraction no 7, migrating with the tracking dye. This fraction with $R_{m}=1.0$ is most probably composed of small peptides. Three fractions (no $4,5,6$ ) with fast electrophoretic mobilities $\left(\mathrm{R}_{\mathrm{m}}=0.36,0.44\right.$ and 0.85 respectively) also represent a small part of total soluble proteins of protein spectra of the two larval stages of the bee. The main part of larval proteins, slowly moving large protein complexes forming band no 1 and closely-spaced fractions nos 2-3, represent as much as 72.07-85.94\% of the proteins in the coiled larvae and $74.53-87.54 \%$ in upright larvae. Although the density of haemolymph proteins fluctuates among individuals and between the two developmental stages, statistical analysis revealed a significant difference $(P \leqslant 0.01)$ in the content of the protein that represents band 1 in coiled and in upright larvae. However, the mean levels of six other proteins (no 2-7) in haemolymph of coiled and upright larvae are not statistically different $(P \geqslant 0.05)$.

Further fractionation of larval blood proteins was obtained by the onedimensional immunoelectrophoresis technique. As shown in Fig. 3 and 4 the 


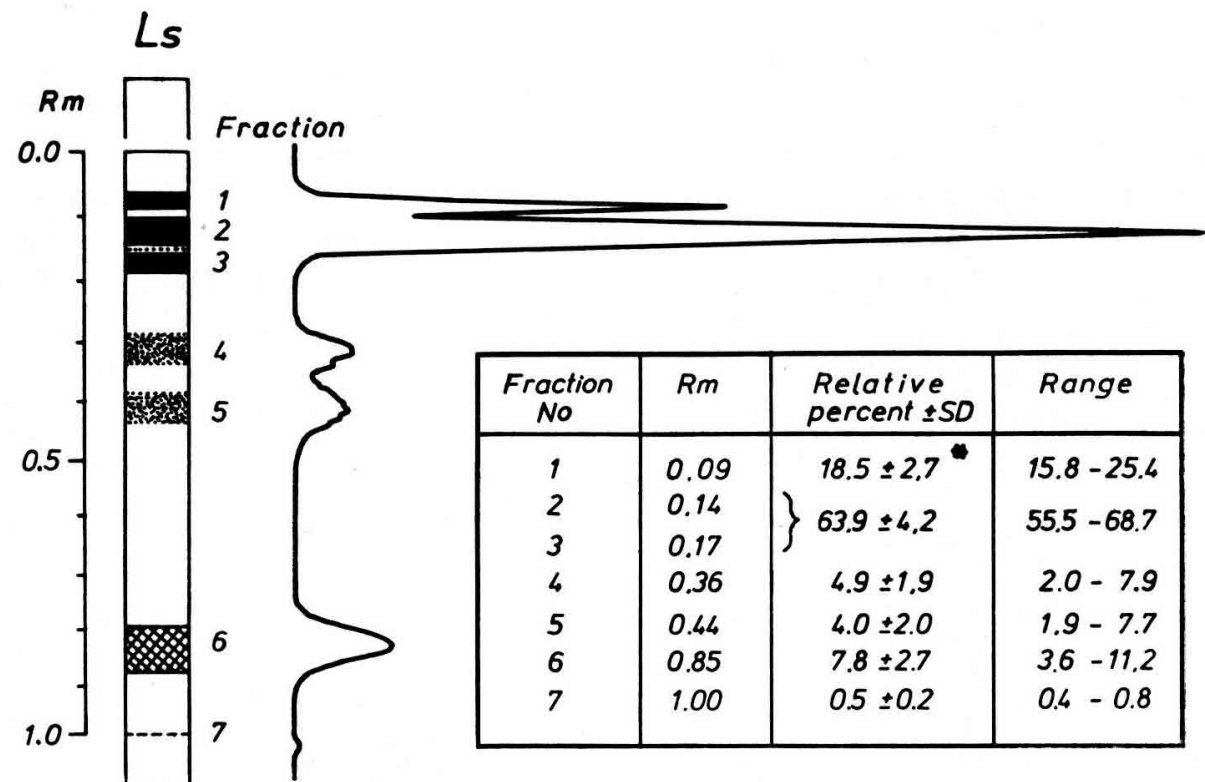

FIG. 2. - Polyacrylamide gel electrophoresis pattern of soluble Apis blood proteins of upright larva (Ls) and densitometer scan of the gel after non-dissociating electrophoresis of proteins in $10 \%$ acrylamide

* denotes statistically significant différences $(P \leq 0.01, \mathrm{n}=12)$

precipitation arcs differ slightly both by their intensity and localization on the immunoelectrophoregrams. It is clear that the size and intensity of the arcs may vary due to the relative differences in concentration of proteins in both haemolymphs (see Fig. 1 and 2). Bandes nos 1-3, 13 and $A$ move towards the cathode, arcs nos 4-7 show only a slight electrophoretic mobility towards the anode, other five bands $(8,9,10,12$ and $B)$ move toward the anode.

There is little change in the number of antigens in larval haemolymph of the both stages. An analysis of immunoelectrophoresis plates shows fifteen distinct antigens in haemolymph of the upright larva and fourteen in the coiled larva. One new antigenic protein that forms precipitation arc no 13 is in the haemolymph of upright larvae. As shown in Fig. 3 and 4, four precipitation lines nos 4-7 overlap; the corresponding antigens are therefore identical in the two stages of larvae. Precipitation lines A and B are produced by haemolymph of both coiled and upright larvae against upright larval antiserum, but they are absent following diffusion against coiled larva antiserum, thereby indicating a small concentration of proteins in coiled larvae to form a detectable precipitation $\operatorname{arcs} \mathrm{A}$ and $\mathbf{B}$. 
Because of the difficulty of determining serological identity of the other larval proteins by immunoelectrophoresis plate analysing, the cross-absorption test reveals the serological identities of the fourteen larval proteins present in the cell-free blood of the both developmental stages of larvae studied. Following immunodiffusion with the cross absorbed antisera, no bands are present with coiled larval haemolymph, but one precipitation arc is visualized when upright larvae haemolymph and corresponding antiserum absorbed with haemolymph of coiled larvae are used. It is therefore postulated that this faint precipitation line no 13 , formed only in immunoelectrophoresis using upright larval haemolymph as the antigens against its specific antibodies, is a new unique protein of the upright larva.

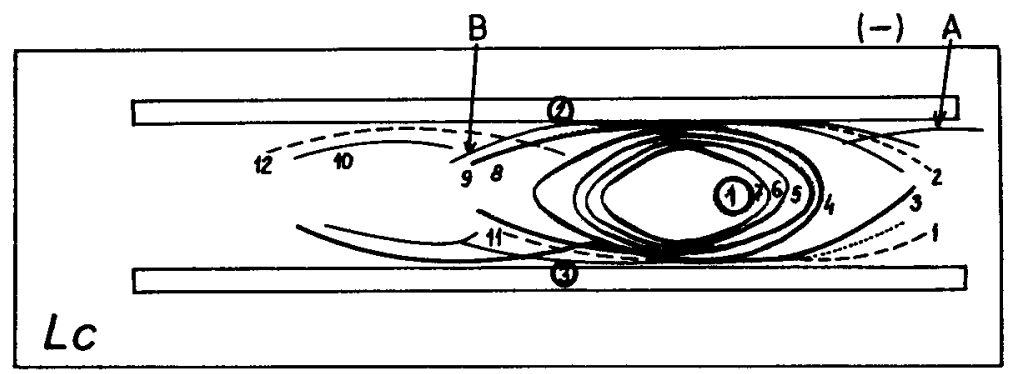

FIG. 3. - An immunoelectrophoresis plate and immunoelectropherogram analysing coiled larval blood proteins of A. mellifera

Antiserum against upright larval proteins is in the trough on the top (2); that against coiled larval proteins is in the bottom (3), central well (1) contains cell-free haemolymph of coiled larva (sce details in the text).

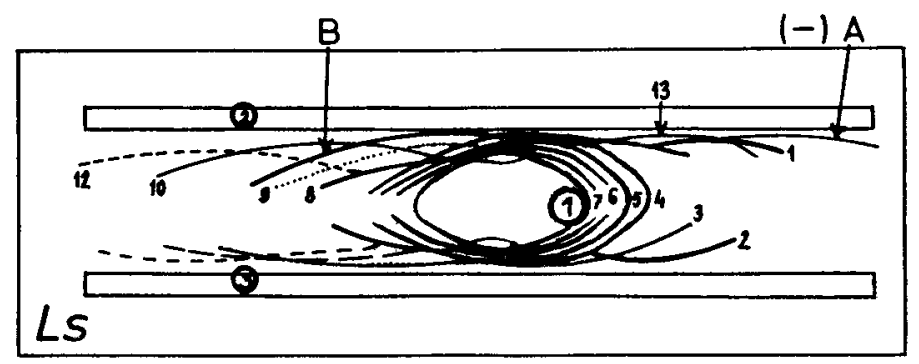

FIG. 4. - An immunoelectrophoresis plate and immunoelectropherogram analysing upright larval blood proteins of A. mellifera

Antiserum against upright larval proteins is in the trough on the top (2); that against coiled larval proteins is in the bottom (3), central well (1) contains cell-free haemolymph of upright larva (see details in the text). 


\section{DISCUSSION}

An analysis of the native complexes of soluble blood proteins by the gel electrophoresis revealed at least six major protein complexes that could always be found in both larval stages. Statistical comparisons of the complexes have provided evidence that the protein spectra of the larval stages differ statistically $(\mathrm{P} \leqslant 0.01)$ only by the component(s) of protein(s) forming fraction 1 . Statistical differences $(P \geqslant 0.05)$ between mean values of all other soluble fractions did not occur.

When soluble blood proteins were fractionated with the same buffer systems on $16 \%$ separation gel instead of the $10 \%$ gel used herein, additional minor protein bands occurred in the separation gel (data unpublished). Moreover, it is also evident that separation of blood proteins after dissociation reveals a large number of protein fractions or their subunits (GLINSKI and JAROSZ, 1985). It is suggested that fraction no 1 with closely-spaced fractions 2-3 which contain above $70.0 \%$ of the total proteins in blood of the both stages dissociate in the presence of SDS and beta-mercaptoethanol into a great number of subunits that form separate bands on acrylamide gel. That honey bee blood protein aggregates confirms fully the results of analysis of blood samples by onedimensional immunoelectrophoresis and indicates that if not all at least some protein complexes are composed of several soluble proteins with immunological activity. In intact samples of blood they must occur as protein complexes that after injection into rabbits stimulate the production of specific antibodies. It is also clear that fourteen arcs obtained in immunoelectrophoresis plates of coiled larval blood and fifteen in upright one do not point to the number of total protein fractions or their subunits in the blood but indicate only the number of immunoreactive proteins.

Although separation of blood proteins on acrylamide gel gave the same number of protein fractions in the both developmental stages, immunological analysis reveals a quantitative difference between the coiled and upright larvae. The appearance of arc no 13 in blood of upright larvae and its lack in coiled larvae indicates the presence of a unique specific protein in blood of upright larvae and the existence only minute developmental changes in protein spectra of both larval stages of the bee. Finally, on the basis of the presented evidence, it is reasonable to assume that the total number of protein fractions in undegraded larval blood is not numerous; and it does not exceed 15 proteins. In general, all but one (no 13) protein in coiled and upright larvae are serologically identical. 


\title{
CONCLUSIONS
}

1. The protein spectra of undegraded proteins in larval blood from the two developmental stages of the worker bee are similar. The number of groups of unresolved protein complexes is not great but protein complexes are numerous, and only six complexes occur both in coiled and upright larvae.

2. Statistical comparisons of protein complexes reveal significant differences $(P \leqslant 0.01)$ only between the content of one protein or protein complex; others, however, do not differ statistically at the level of $P \leqslant 0.05$.

3. Six protein complexes are composed of at least 14 immunoreactive proteins in coiled larvae and 15 ones in upright larvae. Fourteen proteins are serologically identical in the both larval stages, and one is an unique protein for upright larvae.

Received for publication in February 1985.

Accepted for publication in Jlly 1985.

\author{
RÉSUMÉ \\ ANALYSE PAR IMMUNOELLCTROPHORESE DES PROTÉNAES SOLUBLES \\ DE L'HÉMOLYMPHE DES LARVES ENROULEES ET ALLONGEES \\ DES OUVRIERES D'ABEILLE (APIS MELLIFICA L.)
}

Pour analyser les composés protéiniques de l'hémolymphe des larves enroulées et allongées d'Apis mellifica, on a utilisé l'électrophorèse sur gel d'acrylamide dans un système de tampon non dénaturant (LAEMmLi, 1970) et l'immunoélectrophorèse à une dimension (Grabar et Williams, 1955).

Le fractionnement primaire des complexes non dégradés des protéines solubles conduit à 6 fractions principales et une fraction mineure supplémentaire, composée d'acides aminés libres et qui migre avec le colorant porteur $\left(\mathrm{R}_{\mathrm{m}}=1,0\right)$. Les composés protéiniques 1,2 et 3 qui migrent lentement $\left(\mathrm{R}_{\mathrm{m}}=0,09 ; 0,14\right.$ et 0,17 respectivement $)$ ont une forte proportion de protéines, de 72,07 à $85,94 \%$ pour les larves enroulées et de 74,53 à $87,54 \%$ pour les larves allongées. Les densités des protéines de l'hémolymphe varient d'un individu à l'autre pour les 2 stades et seule la teneur en protéines de la fraction 1 est statistiquement différente chcz. les larves enroulées et les larves allongées $(\mathrm{P} \leq \mathbf{0 , 0 1 )}$.

La technique immunologique utilisée ici permet un fractionnement plus poussé des protéines larvaires et leur comparaison entre les 2 stades de développement (larve enroulée, larve allongée) très proche l'un de l'autre. En utilisant des antisérums de lapins fabriqués à partir d'hémolymphes dépourvues de cellules comme antigènes, on a pu mettre en évidence par immunoélectrophorèse à une dimension 14 protéines antigéniques détectables chez les larves enroulées et 15 chez les larves allongées. L'arc de précipitation $\mathrm{n}^{\circ} 13$ des larves allongées montre que cette protéine n'est présente qu’à ce stade de développement. Les immunoélectrophorèses effectućes avec des antisérums cross-absorbés révèlent l'identité sérologique des 14 protéines antigéniques des 2 stades larvaires et l'absence de la protéine 13 dans l'hémolymphe des larves enroulées. 
On a utilisé diverses techniques d'électrophorèse sur gel d'acrylamide pour séparer les protéines de 1'hémolymphe d'abeille. Manifestement les résultats obtenus ne sont pas comparables. Bien que de nombreuses bandes protéiniques soient visibles sur les gels d'acrylamide dans divers système tampon, l'électrophorèse sur $10 \%$ de gel d'acrylamide sans dodécylsulfate de sodium ne montre que 6 groupes principaux de complexes protéiniques naturels chez les 2 stades. L'analyse immunoélectrophorétique des échantillons d'hémolymphe confirme la nature complexe des protéines qui forment les 6 bandes bien définies sur gel d'acrylamide. L'utilisation d'immunosérums dirigés contre les protéines larvaires permet de supposer la présence d'une protéine antigénique supplémentaire dans l'hémolymphe des larves allongées, indiquant une modification de la composition de l'hémolymphe liée à la physiologie du développement.

\section{ZUSAMMENF ASSUNG}

\section{EINE IMMUNELEKTROPHORETISCHE ANALYSE DER LÖSLICHEN BLUT-PROTEINE VON RUND- UND STRECKLARVEN VON APIS MELLIFERA}

Zur Analyse der Proteinkomponenten im Blut von Rund- und Strecklarven der Honigbiene wurde die Acrylamidgel-Elektrophorese mit dem nicht-denaturierenden Puffersystem LAEMmLI (1970) und die eindimensionale Immunelektrophorese nach Grabar und WILL.IAmS (1955) angewandt. Die primäre Fraktionierung der unbehandelten Komplexe der löslichen Blutproteine in der larvalen Haemolymphe ergab schließlich sechs Hauptfraktionen und eine zusätzliche kleinere Fraktion, die zusammen mit dem Trägerfarbstoff $\left(R_{m}=1,0\right)$ bestehend aus freien Aminosäuren, wanderte. Die langsam wandernden Proteinkomponenten 1,2 und $3\left(\mathrm{R}_{\mathrm{m}}=0,09 ; 0,14\right.$ und 0,17$)$ stellten den Hauptanteil der Proteine, und zwar 72,07-85,94\% bei Rundlarven und 74,53-87,54\% bei Strecklarven. Die Konzentration der Haemolymphproteine schwankte bei den Individuen beider Stadien, aber nur bei den Proteinen der Fraktion 1 waren die Unterschiede zwischen Rund- und Stecklarven signifikant $(\mathrm{P} \leq 0,01)$.

Die hier angewandte Immunotechnik ermöglicht eine weitere Fraktionierung von Larvenproteinen und deren Vergleich bei den beiden entwicklungsphysiologisch eng verwandten Stadien der Biene. Bei der Benutzung zellfreier Haemolymphe und Kanichen-Antiserum, ergibt die eindimensionale Immunelektrophorese bei Rundlarven 14 erkennbare immunoreaktive Proteine und bei Strecklarven 15 Proteine. Praezipitationsbogen Nr. 13 am Immunoelektropherogramm von Streckmaden zeigt ein besonderes Protein an, das nur in dicsem Entwicklungsstadium der Biene vorhanden ist. Immunoelektrophorese mit kreuzabsorbierten Antisera ergibt die Identität von 14 immunoreaktiven Proteinen beider Larvenstadien und das Fehlen von Protein 13 in der Rundlarven-Haemolymphe.

Mehrere Techniken der Acrylamidgel-Elektrophorese wurden angewandt, um die Haemolymphproteine der Biene $z u$ trennen; die erzielten Resultate sind offensichtlich nicht miteinander vergleichbar. Obwohl auf Acrylamidgel unter verschiedenen Puffersystemen zahlreiche Proteinbänder dargestellt werden, ergibt die Elektrophorese auf $10 \%$ Acrylamid-Trennungsgel ohne Benutzung von Natriumdodecylsulfat nur sechs native Proteinkomplexe im Blut beider Stadien. Die immunelektrophoretische Analyse von Blutproben bestätigt die komplexe Natur der Blutproteine, die auf Acrylamidgel sechs gut definierte Banden ergeben. Außerdem ergibt der serologische Vergleich von Larvenproteinen die Anwesenheit eines besonderen immunoreaktiven Proteins im Blut von Strecklarven, wodurch eine entwicklungsphysiologische Änderung in der Haemolymphzusammensetzung angezeigt wird.

\section{REFERENCES}

Bounias M., 1975. - Les protéines de l'hémolymphe chez l'Abeille, Apis mellifica mellifica L.I. Larves, nymphes et adultes naissantes. Apidologie, 6, 207-218. 
Chen P.S., Levenbook C., 1966. - Studies on the haemolymph proteins of the blowfly Morunia regina. Changes in ontogenic patterns. J. Insect Physiol., 12, 1599-1609.

GLINSKI Z., Jarosz J., 1985. - Distribution of protein fractions in haemolymphs of worker honey bee brood, Apis mellifera. J. Apic. Res., 24. In press.

Grabar P., Williams C.A. Jr, 1955. - Méthode immuno-électrophorétique d'analyse de mélanges de substances antigéniques. Biochem. Biophys. Acta, 17, 67-82.

LAEMmLI U.K., 1970. - Clavage of structural proteins during the assembly of the heat of bacteriophage $\mathrm{T}_{4}$. Nature, 227, 680-685.

LENSKY Y, 1971. - Haemolymph proteins of the honey bee. II. Differentiation during the development of bee workers. Comp. Biochem. Physiol., 39, 335-341.

Norman M., Lusk G.J., Wiygul G., 1967. - In The Physiology of Insecta, II ed. Edited Rockstein M., vol. 5, Academic Press, London, $300 \mathrm{p}$.

Parker R., 1971. - A comparison of heamolymph proteins in two species of Leptinotarsa beetles. J. Insect Physiol, 17, 1689-1698.

TaKeI G.H., Tamashiro M., 1975. - Changes observed in haemolymph proteins of the Lawn armyworm, Spodoptera mauritia acronyctoides, during growth, development, and exposure to a nuclear polyhedrosis virus. J. Insect Pathol., 26, 147-158.

ToRunen S., 1978. - Soluble proteins and lipoproteins in Pieris brassicae L. (Lepidoptera, Pieridae) : developmental changes and distributional differences. Ann. Zool. Fennici., 15, 94-98.

Young III S.Y., ScotT H.A., 1970. - Immunoelectrophoresis of haemolymph of the Cabbage looper, Trichoplusia ni, during the course of a nuclear polyhedrosis virus infection. J. Invertebr. Pathol., 16, 57-62. 